$$
\begin{gathered}
\text { 국방분야 인공지능 저변화를 위한 } \\
\text { 대한민국 국방 인공지능 추진전략 } \\
\text { 이승목*†, 김영곤*, 안경수* }
\end{gathered}
$$

\title{
The AI Promotion Strategy of Korea Defense for the AI Expansion in Defense Domain
}

\author{
Seung-Mok Lee*† , Young-Gon Kim*, Kyung-Soo An*
}

요 약

최근 인공지능은 민간분야에서는 급속히 확산, 대중화 되어 음성인식 개인 서비스 분야로 확대되면서 보급 화 되었고 주요 강대국은 인공지능 추진전략을 수립하였지만 한국 국방분야의 경우에는 분야 특수성과 함께 북한과의 지정학적 위치로 파급력은 낮은 실정이다.

본 논문은 이러한 한국의 국방 인공지능 파급력을 높이고 인공지능을 성공적으로 추진하기 위해 로드맵 확립, 인력 확보, 인공지능 기반 확립, 이해관계자들의 협력 강화 등 총 6 가지 대한민국 국방 인공지능 추진전략을 제시 한다. 또한 제시된 추진전략에 대해서 4 가지 제약사항을 분석하고 극복 방안을 제안함으로써 국방분야의 인공지 능 저변확대를 위해 초석을 다질 수 있을 것으로 기대한다.

\begin{abstract}
Recently, artificial intelligence has spread rapidly and popularized and expanded to the voice recognition personal service sector, and major countries have established artificial intelligence promotion strategies, but in the case of South Korea's defense domain, its influence is low with a geopolitical location with North Korea.

This paper presents a total of six strategies for promoting South Korea's defense artificial intelligence, including establishing roadmaps, securing manpower, installing the artificial intelligence base, and strengthening cooperation among stakeholders in order to increase the impact of South Korea's defense artificial intelligence and successfully promote artificial intelligence. These suggestions are expected to establish the foundation for expanding the base of artificial intelligence.
\end{abstract}

한글키워드 : 국방, 인공지능, 저변화, 성공전략, 추진전략, 극복방안

keywords : Defense, artificial intelligence, Successful Strategy, Promotional Strategy, Overcoming Way

* 한화시스템 항공시스템팀

† 교신저자: 이승목 (email:

seungmok23.lee@hanwha.com)

접수일자: 2021.10.31. 심사완료: 2021.12.07.

게재확정: 2021.12.20.

\section{1. 서 론}

인공지능이란 인간의 지적능력을 컴퓨터로 구 현하는 과학기술로서, 상황을 인지하고, 이성적. 
논리적으로 판단, 행동하며 감성적·창의적인 기 능을 수행하는 능력까지 포함한다[1]. 인공지능은 상당히 오래 전부터 연구되었던 분야이지만 2016 년을 기점으로 인공지능이 대중들에 게 각인이 되 었는데 그 이유는 무한에 가까운 바둑의 수를 학 습한 인공지능 알파고와 이세돌 간의 대국 때문 이었다. 이세돌이 알파고와 대국에서 1-4로 패배 함으로써 대중들은 큰 충격과 더불어 인공지능의 세계가 대중들로 한층 가까이 다가왔음을 피부로 느끼게 되었다. 이를 기점으로 다양한 학습 알고 리즘이 파생되었고 실제 서비스와 함께 상용화 되어 우리 생활 영역으로 깊숙하게 들어오고 있 다. 특히 음성인식 개인 서비스 분야에서 인공지 능의 보급화가 두드러졌으며 네어버는 자체 $\mathrm{AI}$ 플랫폼인 클로버(Clover) 기반의 웨이브(WAVE), 캐릭터를 반영한 프렌즈를, 카카오는 카카오톡과 연계된 카카오 미니를 출시하였다. 삼성전자는 음성비서 빅스비(Bixby)를 탑재한 스피커를 2018 년에 출시하였다[2].

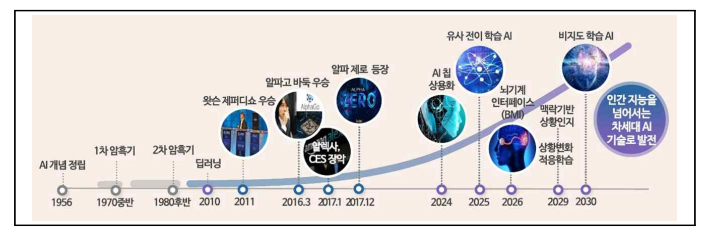

그림 1. 인공지능 발전 추이[3]

Fig 1. The Trend of Al Development

인공지능이 민간분야에는 급속히 스며들어 현 실화 되고 있는 것과 반대로 국방분야의 확산 및 적용 속도는 민간분야에 미치지 못한 것은 사실 이다. 이는 신뢰성과 안정성이 입증된 기술의 채 택, 데이터의 기밀성과 보안성, 인력 접근 제한 등 국방분야 특수성에 따른 제약으로 인해 국방 분야의 인공지능 전파력은 민간분야 대비 다소 낮다. 그러나 4차 산업혁명으로 인한 기술의 새 로운 패러다임 등장과 출산율의 급격한 하락에
따른 방위인력의 하락으로 인공지능의 국방분야 적용은 필수적이다. 이러한 기술적인 흐름과 함 께 북한, 중국, 일본, 러시아 등의 동북아시아 내 군사적인 우위를 위해서 대한민국의 국방 인공지 능 추진전략은 반드시 필요하지만, 국방분야 인 공지능은 현재 활용 관점에서 집중되어 있고 거 시적인 관점에서의 추진전략은 미비하다.

본 논문은 대한민국 국방 인공지능을 성공적 으로 추진하기 위해 다음과 같은 흐름으로 제시 하고자 한다. 2장에서 관련 연구를 통해 주요 강 대국의 인공지능 추진전략과 인공지능 선도국인 미국의 인공지능 추진전략, 미 국방분야의 인공 지능 추진전략을 분석한다. 3 장에서는 2 장에서의 강대국들의 인공지능 추진전략에 대한 특징을 토 대로 중점사항을 분석한 후, 대한민국 국방 인공 지능 상세 추진전략을 제시한다. 또한 국방 인공 지능 추진전략에 대한 제약사항을 예측, 분석하 고 극복 방안을 함께 제안한 다음, 마지막 4장에 서 결론을 맺는다.

\section{2. 주요 강대국의 인공지능 추진전략과 미국의 인공지능 추진전략}

\section{1 주요 강대국의 인공지능 추진전략}

중국은 먼저 인공지능을 위한 데이터 구축 활 동과 정책을 공격적으로 펼치고 있다. $\mathrm{AI}$ 학습을 위한 공공데이터 구축, 빅데이터 거래소 설립, 데 이터 활용을 위한 개인정보보호 규제 철폐 등 $\mathrm{AI}$ 데이터 이용 활성화의 기반을 구축하는데 초점을 두고 있다[4]. 또한 2015년 중국은 스마트 제조 및 활성화를 위해 $\mathrm{AI}$ 와 결합된 과학기술발전계 획, 중국제조 2025 로드맵 제시하였고, 중국 5개 년 발전 청사진인 '제 13 차 5 개년 계획('16' 22 )에 서 100 대 국가전략 프로젝트를 제시했고, $\mathrm{AI}$ 를 중점 분야로 선정하였다[5]. 
표 1. 중국 ‘차세대 $\mathrm{Al}$ 발전계획'의 3단계 전략 목표[5]

Table 1. The 3 Step Strategy Goal for the Next Generation Al Development Plan of China

\begin{tabular}{|c|c|}
\hline 구분 & 주요 내용 \\
\hline $\begin{array}{c}\text { 1단계 } \\
(\sim 2020)\end{array}$ & $\begin{array}{l}\text { - } \mathrm{AI} \text { 제반 기술 및 응용 분야에서 세 } \\
\text { 계 선진국 수준 도달 } \\
\text { - } \mathrm{AI} \text { 산업을 새로운 경제성장축으로 } \\
\text { 육성하고 이를 통해 민생 개선 } \\
\text { - 이론 및 기술의 진전을 통한 중국 } \\
\text { 인공지능 산업의 글로벌 경쟁력 } \\
\text { 제고 } \\
\rightarrow \text { 핵심 산업 규모 } 1500 \text { 억 위안 이 } \\
\text { 상, 연관 산업 규모 } 1 \text { 조 위안 이 } \\
\quad \text { 상 확대 }\end{array}$ \\
\hline $\begin{array}{c}\text { 2단계 } \\
(\sim 2025)\end{array}$ & $\begin{array}{l}\text { - } \mathrm{AI} \text { 기초이론의 획기적 돌파구 마 } \\
\text { 련 } \\
\text { - 일부 기술·응용 면에서 세계 선두 } \\
\text { 수준에 도달 } \\
\text { - 중국의 산업고도화와 경제 발전을 } \\
\text { 선도하는 주요 원동력으로서 지능 } \\
\text { 형 사회 건설의 적극적 역할 수행 } \\
\rightarrow \text { 핵심 산업 규모 } 4000 \text { 억 위안 이 } \\
\text { 상, 연관 산업 규모 } 5 \text { 조 위안 이 } \\
\text { 상 확대 }\end{array}$ \\
\hline $\begin{array}{c}\text { 3단계 } \\
\text { ( 2030) }\end{array}$ & $\begin{array}{l}\text { - } \mathrm{AI} \text { 이론, 기술 및 응용이 글로벌 선 } \\
\text { 도 수준에 도달하여 세계 주요 } \mathrm{AI} \\
\text { 혁신 중심지로 도약 } \\
\text { - 세계 } \mathrm{AI} \text { 혁신의 중심 국가 지위 획 } \\
\quad \text { 득 } \\
\rightarrow \text { 핵심 산업 규모 } 1 \text { 조 위안 이상, 연 } \\
\text { 관 산업규모 } 10 \text { 조 위안 이상 확대 }\end{array}$ \\
\hline
\end{tabular}

일본은 경제 부진 탈피와 사회문제 해결 등 국 가의 제반 과제를 $\mathrm{AI}$ 와의 결합을 통해 해결하는
기회로 활용하는 정책을 추진하고 있다[4]. ICT 를 활용하여 사이버공간과 현실사회를 뛰어넘어 자유롭게 활동이 이루어지는 초스마트사회 (Society5.0)를 제시하고[5] 특히, 3단계에 걸친 $\mathrm{AI}$ 산업화 로드맵을 통해 궁극적으로 선순환을 위한 에코시스템을 구축하고자 한다. 또한 인공 지능에 대해서 중요성을 인식하고 초스마트 사회 를 위한 초석 기술로 인식하고 있으며 $\mathrm{AI}$ 등 민 간 주도로 연구개발 추진이 힘든 것은 국가전략 핵심 기술로 분류하여, 장기적으로 추진할 것을 제안하였다[5]

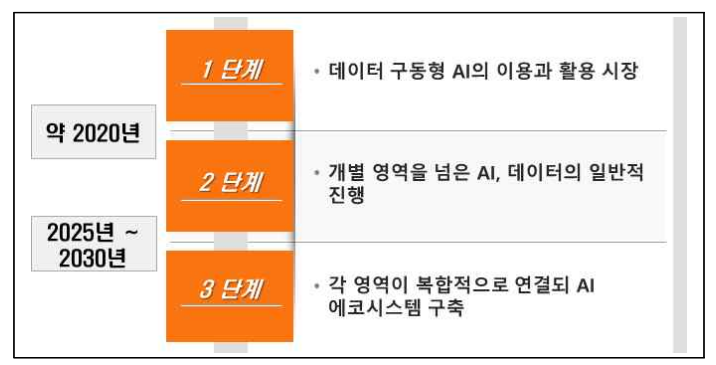

그림 2. 일본 $\mathrm{Al}$ 산업화 로드

Fig 2. The Roadmap for Al Industrization of Japan

표 2. 일본의 Al 산업화 단계별 예시[5]

Table 2. The examples for Al Industrization of Japan each step

\begin{tabular}{|c|c|}
\hline 구분 & 주요 내용 \\
\hline 1 단계 : & - (공간이동) 무인공장, 무인농업 \\
2020 년 & 기술 확립 \\
까지 & - (생산성) 생산설비 고장 예측 \\
& - (건강) $\mathrm{AI}$ 를 이용한 신약 개발 \\
\hline & - (공간이동) 물건의 운송, 배송의 \\
2 단계 : & 완전 무인화 \\
2025 년 & - (생산성) 가전을 $\mathrm{AI}$ 로 제어, 다기 \\
2030년 & 능 로봇 확대, 로봇 간 협조 \\
& - (건강) 개인맞춤형 신약개발 \\
\hline
\end{tabular}


표 2. 일본의 $\mathrm{Al}$ 산업화 단계별 예시(계속)

Table 2. The examples for Al Industrization of Japan each step(Continued)

\begin{tabular}{|c|c|}
\hline 구분 & 주요 내용 \\
\hline $\begin{array}{c}\text { 3단계 : } \\
\text { 2030년 } \\
\text { 이후 }\end{array}$ & $\begin{array}{l}\text { - (공간이동) 이동자유화. 무인화 } \\
\text { 가 실현되면서 인간에 의한 사 } \\
\text { 망사고율 제로사회 } \\
\text { - } \text { (생산성) 사람의 잠재의식까지 } \\
\text { AI가 분석 } \\
\text { - (건강) 간병 로봇은 가족의 구성 } \\
\text { 원 중 하나로 인식 }\end{array}$ \\
\hline
\end{tabular}

영국은 인공지능 생태계 확립에 투자를 많이 하였다. 관련 활동으로 $\mathrm{AI}$ 스타트업 육성을 위해 2018년에 13억 달러를 투자했고, 이미 약 500개 의 $\mathrm{AI}$ 스타트업을 보유하고 있는데, 이는 유럽 전체의 $1 / 3$ 수준(2019년 현재)에 달한다[4]. 또한 AI Sector Deal을 2018년도에 발표를 하였는데 이는 $\mathrm{AI}$ 산업의 5 가지 기본요소(아이디어, 사람, 인프라, 기업 환경, 지역)를 강화하고, 민관의 강 력한 파트너십 구축을 위한 세부 전략 제시[5]가 주요 골자이다. 또한 '인공지능 분야 민관합의'를 통해 산-관-학 파트너십을 기본적인 정책추진 프레임워크로 삼고, 영국 $\mathrm{AI}$ 산업의 글로벌 선도 및 중장기적 민관 혁신 $\mathrm{AI}$ 생태계 구축에 주력하 고 있다[4].

\section{2 주요 강대국의 인공지능 추진전략}

\subsection{1 미국의 인공지능 추진전략}

미국은 오바마 정부부터 $\mathrm{AI}$ 활성화를 위해 전 략과 정책을 수립을 하였다. 그리고 트럼프 행정 부 전환 후 인공지능에 대해 매우 공격적인 전략 을 추진하고 있다. 특히 트럼프 대통령은 인공지
표 3. 주요 국가 Al 추진 현황[4]

Table 3. The Major Contries of Al Progress

\begin{tabular}{|c|c|c|c|}
\hline 구분 & 중국 & 일본 & 영국 \\
\hline $\begin{array}{l}\text { 주요 } \\
\text { 정책 }\end{array}$ & $\begin{array}{l}\text { - } \quad \text { 중국제조 } \\
2025 \\
\text { - 국가정보 } \\
\text { 화 발전 } \\
\text { 전략개요 } \\
\text { - 차세대 } \mathrm{AI} \\
\text { 발전 계획 }\end{array}$ & $\begin{array}{l}- \text { 초스마트 } \\
\quad \text { 사 회 } \\
\text { (Society } \\
\text { 5.0) } \\
\text { - AI 산업화 } \\
\text { 로드맵 } \\
-\quad \text { AI 전략 } \\
2019\end{array}$ & $\begin{array}{c}\text { - 산업전략 } \\
\text { 정책백서 } \\
\text { - 인공지능 } \\
\text { 분야 민 } \\
\text { 관 합의 } \\
\text { (AI Sector } \\
\text { Deal) }\end{array}$ \\
\hline $\begin{array}{l}\text { 인공 } \\
\text { 지능 } \\
\text { 적용 } \\
\text { 주요 } \\
\text { 분야 }\end{array}$ & $\begin{array}{l}\text { 의료, 교통, } \\
\text { 농업, 금융, } \\
\text { 물류, 교육, } \\
\text { 문화, 여행 }\end{array}$ & $\begin{array}{l}\text { 복지 (건강, } \\
\text { 의료, 돌 } \\
\text { 봄), 농업, } \\
\text { 국가 안전 } \\
\text { 및 재난 방 } \\
\text { 지, 교통 인 } \\
\text { 프라, 물류, } \\
\text { 스마트시티 }\end{array}$ & $\begin{array}{l}\text { 생 명 과학, } \\
\text { 자동차, } \\
\text { 창조산업, } \\
\text { 인 공 지 능, } \\
\text { 건설, 핵에 } \\
\text { 너지, } \\
\text { 우주 항 공, } \\
\text { 철도 }\end{array}$ \\
\hline 특징 & $\begin{array}{l}\text { 정부와 대 } \\
\text { 기업 중심 } \\
\text { 의 추진 }\end{array}$ & $\begin{array}{l}\text { 정부 부처 } \\
\text { 및 기업을 } \\
\text { 통한 민관 } \\
\text { 협동 선순 } \\
\text { 환 구조 }\end{array}$ & $\begin{array}{l}\text { 영국정부의 } \\
\text { 산업 전략 } \\
\text { 챌린지 펀 } \\
\text { 드를 통해 } \\
\text { 자금 지원 }\end{array}$ \\
\hline
\end{tabular}

능 분야의 글로벌 리더십 유지 및 강화를 위해 국가 전략 프레임워크로써 '미국 $\mathrm{AI}$ 이니셔티브' 행정명령에 서명('19.3) 하였다[6]. 주요 내용으로 는 오바마 행정부의 7대 전략으로부터 8대 전략 으로 확대하면서 민간 기업과 정부 간 협력적 파 트너십 강화 내용을 추가 하였다. 
표 4. 미국의 Al R\&D 8대 전략[6]

Table 4. Al R\&D 8 Strategy of USA

\begin{tabular}{|c|c|}
\hline & 세부 내용 \\
\hline 전략 1 & $\begin{array}{l}\text { (장기적인 } \mathrm{AI} \text { 연구 투자) } \\
\text { 차세대 } \mathrm{AI} \text { 에 대한 투자 우선순위 부여 }\end{array}$ \\
\hline 전략 2 & $\begin{array}{l}\text { (효과적인 인간-AI 협업) } \\
\text { 사람과 } \mathrm{AI} \text { 시스템 간의 효과적인 상 } \\
\text { 호작용 창출 관련 연구 강화 }\end{array}$ \\
\hline 전략 3 & $\begin{array}{l}\text { (AI의 윤리, 법, 사회적 영향 분석 대응) } \\
\mathrm{AI} \text { 기술의 윤리/법제/사회적함의 이 } \\
\text { 해 기반 } \mathrm{AI} \text { 시스템 설계 방법론 연구 }\end{array}$ \\
\hline 전략 4 & $\begin{array}{l}\text { (AI 시스템의 보안, 안전 보장) } \\
\text { 안정적이며 신뢰할 수 있는 } \mathrm{AI} \text { 시스 } \\
\text { 템을 위한 추가적 연구 진행 필요 }\end{array}$ \\
\hline 전략 5 & $\begin{array}{l}\text { (AI 훈련, 테스팅을 위한 공유 공공 } \\
\text { 데이터, 환경 개발) } \\
\text { 데이터 자원 테스팅과 훈련뿐만 아니 } \\
\text { 라 고품질의 데이터셋에 대한 책임있 } \\
\text { 는 접근성과 고품질 데이터셋 및 환 } \\
\text { 경 개발을 위한 연구를 강화 }\end{array}$ \\
\hline 전략 6 & $\begin{array}{l}\text { (AI 훈련, 표준 및 벤치마크를 활용 } \\
\text { 한 } \mathrm{AI} \text { 기술 측정, 평가) } \\
\mathrm{AI} \text { 기술 발전은 } \mathrm{AI} \text { 의 발전 방향을 제 } \\
\text { 시하고 평가하기 위한 표준, 벤치마 } \\
\text { 크, 테스트베드, 커뮤니티의 참여가 } \\
\text { 핵심이므로, } \mathrm{AI} \text { 시스템에 대한 다양 } \\
\text { 한 평가 기법 개발 필요 }\end{array}$ \\
\hline 전략 7 & $\begin{array}{l}\text { (국가 } \mathrm{AI} \mathrm{R} \mathrm{DD} \text { 인력수요 파악) } \\
\mathrm{AI} \text { 연구 커뮤니티 참여, } \mathrm{AI} \text { 분야의 } \\
\text { 현재와 미래 } \mathrm{R} \& \mathrm{D} \text { 인력에 대한 이해 } \\
\text { 강화 필요 }\end{array}$ \\
\hline 전략 8 & $\begin{array}{l}\text { (AI 발전 촉진을 위한 민관 협력 확대) } \\
\text { 지속적인 } \mathrm{AI} R \& \mathrm{D} \text { 투자와 } \mathrm{R} \& \mathrm{D} \text { 결과 } \\
\text { 물의 상업적 활용 기회를 촉진 }\end{array}$ \\
\hline
\end{tabular}

또한, 미국은 6 대 분야별 $\mathrm{AI}$ 지원정책을 통해 서 인력, 기술, 규제완화를 위한 프로세스, 국제 협력까지 지원을 하고 있다.

표 5. 미국 대중을 위한 Al[7]

Table 5. Artificial Intelligence For The American People

\begin{tabular}{|c|c|}
\hline 분야 & 세부 내용 \\
\hline R\&D & $\begin{array}{l}\text { - AI, 컴퓨팅 인프라, 머신러닝, 자율 } \\
\text { 시스템 등 } \mathrm{AI} \text { 관련 유망기술 } \mathrm{R \& D} \\
\text { 우선 지원 }\end{array}$ \\
\hline 규제 & $\begin{array}{l}\text { - 자율주행, 드론, 헬스케어 등 } \mathrm{AI} \text { 관 } \\
\text { 련 신산업 규제를 우선적 개혁 } \\
\text { * 연방항공청(FAA), 상업·공공 목적 } \\
\text { 의 드론 시범 프로젝트 관련 규제 } \\
\text { 완화 } \\
\text { * 식품의약청(FDA), } \mathrm{AI} \text { 기반 의료기 } \\
\text { 기 사용 허가 }\end{array}$ \\
\hline 양성 & $\begin{array}{l}\text { - 산업계 인정견습 프로그램(Industry } \\
\text { recognized Apprenticeships) 확대 } \\
\text { - STEM 교육 확대를 위한 매칭펀드 } \\
\text { 조성 }\end{array}$ \\
\hline 국가 & $\begin{array}{l}\text { - } \mathrm{AI} \text { 기술을 군사적으로 적용하기 위 } \\
\text { 해 광범위한 투자 추진 }\end{array}$ \\
\hline $\begin{array}{l}\text { 정부 } \\
\text { 서비 } \\
\text { 스 }\end{array}$ & $\begin{array}{l}\text { - 정부서비스 효율성 향상 및 연방데 } \\
\text { 이터 활용 극대화를 위해 자동화 } \\
\mathrm{SW} \text { 를 도입하고, } \mathrm{AI} \text { 활용 시범사업 } \\
\text { 추진 }\end{array}$ \\
\hline 협력 & $\begin{array}{l}\text { - OSTP가 G7 혁신 장관회의의 } \mathrm{AI} \text { 성 } \\
\text { 명서 작성('18.3) } \\
\text { - 미-영, 미-프 간 } \mathrm{AI} \mathrm{R \& D} \mathrm{협력을} \mathrm{위} \\
\text { 한 과학기술 협정 체결 예정 }\end{array}$ \\
\hline
\end{tabular}




\subsection{2 미 국방분야의 인공지능 추진전략}

트럼프는 행정부는 '국가안보전략('17.12), '국 가방위전략('18.1)에서 국가 안보를 위해 $\mathrm{AI}$ 를 투 자 우선순위에 두고 기술 경쟁력을 유지해야 한 다고 강조하였다[6]. 또한, 미 국방부는

(1) 전 세계 미군과 자국민의 보호 및 지원

(2) 국가 방호와 국민의 수호

(3) 직접 통제가 가능한 효율적 조직의 신설

(4) 인공지능 분야에 대한 전 세계적 개척자 역 할 수행[8]

을 위해 '국방부 AI 전략'을 수립하면서 국방분 야의 $\mathrm{AI}$ 확대를 위해 만전을 기하고 있다.

표 6. 미 국방부 $\mathrm{Al}$ 전략 주요 내용[6] Table 6. Al Major Strategy of US Defence

\begin{tabular}{|c|c|}
\hline 전략 & 주요내용 \\
\hline $\begin{array}{c}\text { 핵심 임무 } \\
\text { 수행을 }\end{array}$ & - 상황인식 및 의사결정 능력 향상 \\
위한 $\mathrm{AI}$ & - 예측 융비의 완린전성 깇 공급 첩 \\
적용 몌 & 확립 \\
확산 & - 유연한 업무 프로세스 구축 \\
\hline & - 산학의 개방적 공조를 통해 \\
& 글로벌 문제 해결을 위한 $\mathrm{AI}$ \\
민관 & 이니셔티브 추진 \\
파트너십 & - 학계 파트너십 강화 및 $\mathrm{AI}$ 혁신 \\
및 & 투자 확대 \\
국제협력, & - 미국 산업계와의 파트너십 강화 \\
동맹 강화 & - 국제협력 및 동맹 강화 \\
& - 오픈소스 커뮤니티 참여 확대 \\
\hline & - 첨단 $\mathrm{AI}$ 응용기술 개발 투자 \\
& 지원을 통해 효과 창출을 위한 \\
& 기회 제공 \\
& - 포괄적 $\mathrm{AI}$ 연수 프로그램 제공 \\
& 과 인재 양성 \\
& - 외부 $\mathrm{AI}$ 전문가 영입 \\
& - 실험을 수용할 수 있는 문화 \\
& 구축 \\
선도적 $\mathrm{AI}$ & \\
인력 양성 & \\
&
\end{tabular}

표 6. 미 국방부 $\mathrm{Al}$ 전략 주요 내용(계속)

Table 6. Al Major Strategy of US Defence(Continued)

\begin{tabular}{|c|c|}
\hline 전략 & 주요내용 \\
\hline $\begin{array}{l}\text { 선도적 } \mathrm{AI} \\
\text { 인력 양성 }\end{array}$ & $\begin{array}{l}\text { - 첨단 } \mathrm{AI} \text { 응용기술 개발 투자 } \\
\text { 지원을 통해 효과 창출을 위한 } \\
\text { 기회 제공 } \\
\text { - 포괄적 } \mathrm{AI} \text { 연수 프로그램 제공 } \\
\text { 과 인재 양성 } \\
\text { - 외부 } \mathrm{AI} \text { 전문가 영입 } \\
\text { - 실험을 수용할 수 있는 문화 } \\
\text { 구축 }\end{array}$ \\
\hline $\begin{array}{l}\mathrm{AI} \text { 윤리와 } \\
\text { 안전선도 }\end{array}$ & $\begin{array}{l}\text { - 국방 분야 AI 원칙 수립 } \\
\text { - 복원력 있고, 견고하고, 신뢰할 } \\
\text { 수 있고, 안전한 } \mathrm{AI} \text { 연구 개발 } \\
\text { 투자 확대 } \\
\text { - '설명 가능한(explainable)' } \mathrm{AI} \\
\text { 에 관한 연구 투자 지속 } \\
\text { - } \mathrm{AI} \text { 연구의 투명성 향상 } \\
\text { - 국제 군사 } \mathrm{AI} \text { 가이드라인 개발 } \\
\text { 주도 } \\
\text { - 민간인 사상 및 여타 부수적인 } \\
\text { 피해 감소를 위한 } \mathrm{AI} \text { 활용 }\end{array}$ \\
\hline
\end{tabular}

2.2.3강대국의 인공지능 추진전략 특징 분석 주요 강대국 인공지능 추진전략을 바탕으로 중국, 일본, 영국 각 나라별로 정리해 볼 때 4 가 지의 특징으로 요약되며 각 특징의 장점과 문제 점은 아래와 같다.

(특징 1-1) 거시적인 관점의 로드맵 수립

$D$ 내용

단계별 추진 목표를 수립하고 목표범위를 넓혀 인공지능의 부가가치를 높이기 위한 Value Chain 및 Ecosystem 구축을 최종목 표로 설정 
$\triangleright$ 장점: 각 단계 별 목표설정으로 인공지능 활용을 위한 체계적 접근 가능

$\triangleright$ 문제점: 각 단계의 로드맵 미 달성에 따른 전체 로드맵에 영향 발생

(특징 1-2) 인공지능을 위한 기반 구축

$\triangleright$ 내용

원활한 인공지능 확대를 위해 인공지능 기 반 기술인 데이터 구축 활동을 진행

$\triangleright$ 장점: 인공지능의 올바른 학습과 평가를 위 한 기반 데이터 정의 가능

$\triangleright$ 문제점: 민감한 데이터에 대한 대응 부재

(특징 1-3) 정부의 적극적인 지원

$\triangleright$ 내용

정부주도의 능동적인 추진과 함께 비용지 원을 위해 예산 확보 노력

$\triangleright$ 장점: 효율적 추진과 영세사업자 발전 지원 가능

$\triangleright$ 문제점: 각종 규제 존재 시 관련 지원의 제 약 발생

(특징 1-4) 민관의 긴밀한 협력

$\triangleright$ 내용

민간기업과 정부, 학계 간의 협력을 통해 $\mathrm{AI}$ 산업을 위한 공동의 노력 투입

$\triangleright$ 장점: 협의체를 구성함으로써 참여자들 간 효율적인 협력이 가능

$\triangleright$ 문제점: 구성원들의 이해타산적 접근이 발 생될 경우 원할한 협의체 구성이 어려움

또한 미국의 인공지능의 추진전략과 미 국방 부의 인공지능 추진전략을 토대로 미국의 인공지 능 추진 특징을 6 가지로 요약 할 수 있다.

\footnotetext{
(특징 2-1) 전문인력 양성

$\triangleright$ 내용

연수 프로그램을 통한 인재 양성 혹은 외부 전문가 영입

$D$ 장점: 핵심인재 양성과 양성 후 즉시 투입
}

가능

$\triangleright$ 문제점: 인력양성에 많은 비용과 시간 소요

(특징 2-2) 인공지능을 위한 기반 구축

$>$ 내용

$\mathrm{AI}$ 훈련 및 테스팅을 위한 공공 혹은 공유 데이터 구축과 고품질의 데이터 마련

$\triangleright$ 장점: 인공지능의 올바른 학습과 평가를 위 한 기반 데이터 정의 가능

$D$ 문제점: 민감한 데이터에 대한 대응 부재

(특징 2-3) 안정적이고 신뢰할 수 있는 인공 지능 연구

$>$ 내용

인공지능 사용에 대해 안정적이며 고신뢰 성 결과도출 위한 연구 수행

$\triangleright$ 장점: 인공지능에 대한 객관적 평가와 검증 이 가능

$\triangleright$ 문제점: 고 신뢰의 인공지능의 검증 관련 전략 부재

(특징 2-4) 정부의 적극적인 지원

$\triangleright$ 내용

예산 마련과 같은 정부주도의 능동적인 추 진 및 규제개혁 수행

$\triangleright$ 장점: 정부가 국가사업으로 적극적으로 나 서 리드하고 적절한 가이드 가능

$\triangleright$ 문제점: 각종 규제 존재 시 관련 지원의 제 약 발생

(특징 2-5) 민관의 긴밀한 협력

$>$ 내용

민간기업과 정부 그리고 학계까지 파트너 십 강화와 함께 국제협력 강화

$\triangleright$ 장점: 협의체를 구성함으로써 참여자들 간 효율적인 협력이 가능

$\triangleright$ 문제점: 구성원들의 이해타산적 접근이 발 생될 경우 원할한 협의체 구성이 어려움

(특징 2-6) 윤리적인 인공지능 활용

$>$ 내용 
국방분야 $\mathrm{AI}$ 원칙과 함께 국제 $\mathrm{AI}$ 가이드 라인 개발 주도

$\triangleright$ 장점: 인공지능을 인류의 발전에 사용하기 위한 윤리적인 공감대 형성 가능

$\triangleright$ 문제점: 여러 이해관계로 인해 형식적인이 고 추상적인 가이드라인으로 전락 가능

위의 10 가지 강대국의 전략 특징을 기반으로 대표적인 7가지 중점사항으로 분석할 수 있으며 각 항목에 대해 특징과 연관관계는 그림 3 과 같 다.

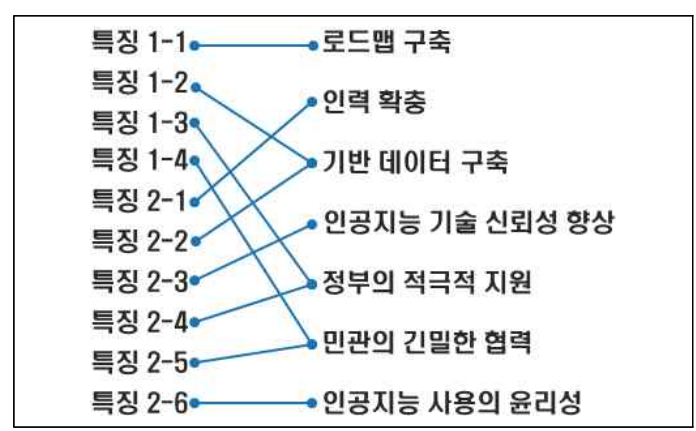

그림 3. 강대국 인공지능 전략 특징별 중점사항

Fig 3. The Main Points from the Al Strategy of Major Countries

\section{3. 대한민국 국방 인공지능 추진전략}

\section{1 대한민국 국방 인공지능 추진전략 수립 을 위한 중점사항}

2 장에서 총 10 가지의 강대국 인공지능 전략 특 징에 대해서 중점항목을 분석하였다. 중점사항을 기반으로 전략 수립을 위한 상세내용은 아래와 같다.

\section{(중점사항 1) 로드맵}

로드맵 확립은 한국형 국방 AI Value Chain과 함께 Ecosystem 을 구축하는 것을 목표로 하면 서 단계적이고 점증적인 로드맵 수립이 필수적이
다. 단계별 목표 수립과 함께 목표수립에 대한 미비점 발견 시 Lesson learn을 활용해 개선하고 로드맵 진행 간 지속적이고 반복적 개선이 필요 하다.

\section{(중점사항 2) 인력}

민간분야에서 $\mathrm{AI}$ 인력 부족률이 평균 $60.6 \%$ 가 부족하다는 설문결과[9]가 나왔고 이는 국방분야 도 예외는 아니며 인력관점에서 국방 인공지능 확립을 위해서 관련 인력 양성은 필수적이다. 하 지만 최신 기술의 변화 시간은 인력 양성에서부 터 활용까지 소요 시간에 비해 극히 짧으므로 외 부 전문 인력의 도입은 효율성 측면에서 매우 중 요하다.

(중점사항 3) 기술 - 데이터 구축/AI 기술

기술관점에서 인공지능 기반을 위한 데이터와 인공지능 자체 기술에 대한 고려가 필요하다. 하 지만 정보시스템 및 무기체계의 기능에 대한 성 능개선은 지속적으로 추진하는 반면, 오류 데이 터 정비, 비표준 데이터의 표준화 등 데이터관리 를 위한 성능개선은 상대적으로 부족한 것으로 보인다[10]. 그러나 데이터는 인공지능의 충분한 학습을 위한 중요요소이므로 충분한 데이터 구축 전략이 필요하다. 또한 인공지능 자체 기술 특히, 알고리즘 측면에서 높은 신뢰성과 안정성이 중요 하다.

\section{(중점사항 4) 이해관계자}

이해관계자관점에서 정부의 단독적인 추진에 는 한계가 존재하므로 민간기관 및 학계 간 긴밀 한 협조가 필요하다.

\section{(중점사항 5) 법과 제도}

법/제도 관점에서 국방 인공지능 추진을 위해 규제의 탄력적인 운영과 규제 개혁까지 고려가 필요하며 비용적 지원 측면도 고려가 필요하다.

(중점사항 6) 거버넌스

인공지능이 인간의 통제를 벗어나 자율적으로 구동하는 과정에서 인간에게 해악을 미칠 수 있 
다[11]. 특히, 국방 인공지능은 타 분야 대비 인 명 살상과 연관되어 있으므로 윤리적 측면과 함 께 국방 인공지능 운영에 대한 관리/통제, 관리/ 통제용 가이드라인 그리고 국방 인공지능 성숙도 가 고려되어야 한다. 즉, 이들을 내포하는 국방 인공지능 거버넌스가 고려되어야 한다.

\section{2 대한민국 국방 인공지능 추진전략 및 상 세설명}

2장의 6가지 고려항목을 토대로 대한민국 국 방 인공지능 추진전략 구성은 그림 4 와 같으며 추진전략 내용은 아래와 같다.

\section{[추진전략 1]}

- 국방 인공지능 추진 로드맵 확립

$\triangleright$ 국방 인공지능 추진을 위한 3단계 로드맵 확립

\section{[추진전략 2]}

- 인력 관점의 우수 인공지능 인력 확보

$\triangleright$ 국방용 인공지능 우수 인력 양성 및 전문 인력 Pool 관리

\section{[추진전략 3]}

- 기술관점의 인공지능 기반 확립 및 인공지 능 알고리즘 연구

$\triangleright$ 인공지능용 학습 데이터 확립과 높은 신 뢰성/안정성을 위한 알고리즘 연구

\section{[추진전략 4]}

- 이해관계자관점의 민·군·정·학 협력 강화

$\triangleright$ 국방 인공지능 발전을 위한 민간기업, 군 과 정부기관, 학계 간 협력 강화

\section{[추진전략 5]}

- 법/제도 관점의 규제개혁과 규제 샌드박스 및 탄력적 지원

$\triangleright$ 국방 인공지능 발전을 위한 규제개혁과 적극적이고 탄력적인 지원

\section{[추진전략 6]}

- 국방 인공지능 거버넌스 확립 $\triangleright$ 국방용 인공지능 관리 및 통제, 가이드라 인 제시와 함께 국방 인공지능 성숙도 유 지를 위한 지속적 개선

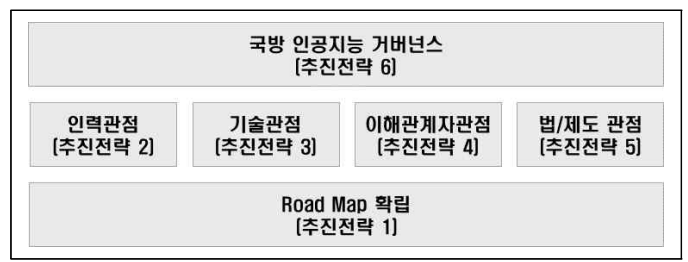

그림 4. 국방 인공지능 추진전략 구성

Fig 4. The Construction of Defense Al Strategy

6 개의 추진전략별 전략 필요성과 상세 전략을 살펴보면,

(추진전략 1) 국방 인공지능 추진 로드맵 확립

\begin{tabular}{|c|c|c|}
\hline \multirow{8}{*}{$\begin{array}{l}\text { 필 } \\
\text { 요 } \\
\text { 성 }\end{array}$} & 국방 & \\
\hline & 인공 & 국방 인공지능 추진전략을 단계 \\
\hline & 지능 & 별로 실행할 수 있는 1 3단계 \\
\hline & 청사진 & 전략이 필요 \\
\hline & 제시 & \\
\hline & 단계별 & 최종 3단계인 선순환구조를 만 \\
\hline & 보완과 & 들기 위해 단계적 보완과 개선 \\
\hline & 개선 & 요구 \\
\hline \multirow{10}{*}{$\begin{array}{l}\text { 상 } \\
\text { 세 } \\
\text { 전 } \\
\text { 략 }\end{array}$} & & - 국방 인공지능 활용을 위한 \\
\hline & & 환경을 구축 \\
\hline & 1단계 & - 데이터 환경 구축 시 국방 특 \\
\hline & & $\begin{array}{l}\text { 수성을 고려한 데이터의 보안등 } \\
\text { 급 정의 }\end{array}$ \\
\hline & & - 전략적인 구축을 위한 주요 \\
\hline & & 사업을 선정, 선정된 사업에 \\
\hline & 2단계 & 인공지능 선 적용 \\
\hline & & - Lesson Learn 및 미비점 보완 \\
\hline & & 을 위한 1,2 단계 iteration 수행 \\
\hline & 3단계 & $\begin{array}{l}\text { 국방 인공지능을 Value Chain화 } \\
\text { 하고 선순환을 위한 Ecosystem } \\
\text { 을 구축 }\end{array}$ \\
\hline
\end{tabular}


(추진전략 2) 인력 관점의 우수 인공지능 인 력 확보

\begin{tabular}{|c|c|c|}
\hline 필 & $\begin{array}{c}\text { 군 } \\
\text { 인공지능 전문 } \\
\text { 인력확보 }\end{array}$ & $\begin{array}{l}\text { 인공지능 적용을 위해 전 } \\
\text { 문적 지식을 보유한 인력 } \\
\text { 활용 }\end{array}$ \\
\hline 성 & $\begin{array}{c}\text { 군 } \\
\text { 인공지능 } \\
\text { 활용능력 배양 }\end{array}$ & $\begin{array}{l}\text { 실 업무 인력에 대한 인 } \\
\text { 공지능 활용 능력 배양 }\end{array}$ \\
\hline $\begin{array}{l}\text { 상 } \\
\text { 세 }\end{array}$ & $\begin{array}{c}\text { 군 내부 } \\
\text { 인력 양성용 } \\
\text { 교육 개발 }\end{array}$ & $\begin{array}{l}\text { - 인공지능 전문 교육 개 } \\
\text { 발 및 커리큘럼 확보 } \\
\text { - 해외 전문가 교육 과정 } \\
\text { 지원 } \\
\text { - 보안성 및 제한성이 요 } \\
\text { 구되는 영역에 활용 }\end{array}$ \\
\hline 략 & $\begin{array}{c}\text { 민간 } \\
\text { 우수인력 활용 }\end{array}$ & $\begin{array}{l}\text { - 인공지능 전문 인력 및 } \\
\text { 우수 인력 Pool 관리 } \\
\text { - 기술적 전문 조언 및 } \\
\text { 신규 제품과 서비스 개발 } \\
\text { 에 활용 }\end{array}$ \\
\hline
\end{tabular}

\begin{tabular}{|c|c|c|}
\hline & $\begin{array}{l}\text { 데이터 및 } \\
\text { 기반 요소 } \\
\text { 식별과 확립 }\end{array}$ & $\begin{array}{l}\text { 국방 인공지능에 활용되는 } \\
\text { 데이터 및 기반 요소 식별 } \\
\text { 후 확립 }\end{array}$ \\
\hline $\begin{array}{l}\text { 상 } \\
\text { 세 }\end{array}$ & $\begin{array}{l}\text { 설명 가능한 } \\
\text { 인공지능 } \\
\text { 알고리즘 } \\
\text { 개발 }\end{array}$ & $\begin{array}{l}\text { 학습과 인지, 판단 프로세 } \\
\text { 스에 근거가 있는, 설명 가 } \\
\text { 능한 인공지능 알고리즘 } \\
\text { 연구 }\end{array}$ \\
\hline $\begin{array}{l}\text { 전 } \\
\text { 략 }\end{array}$ & $\begin{array}{c}\text { 국방 } \\
\text { 인공지능용 } \\
\text { 개발 플랫폼 } \\
\text { 개발 }\end{array}$ & $\begin{array}{l}\text { 군 인공지능 개발과 적용 } \\
\text { 을 위한 국방용 인공지능 } \\
\text { 개발 플랫폼 개발 }\end{array}$ \\
\hline & $\begin{array}{c}\text { 국방 } \\
\text { 인공지능 } \\
\text { 품질 평가 } \\
\text { 모델 개발 }\end{array}$ & $\begin{array}{l}\text { 국방 인공지능 서비스 및 } \\
\text { 제품을 품질 평가를 위한 } \\
\text { 모델 개발 }\end{array}$ \\
\hline
\end{tabular}

(추진전략 3) 기술관점의 인공지능 기반 확립 및 인공지능 알고리즘 연구

\begin{tabular}{|c|c|c|}
\hline \multirow{2}{*}{ 필 } & $\begin{array}{c}\text { 고 신뢰성의 } \\
\text { 연산결과 } \\
\text { 확보 }\end{array}$ & $\begin{array}{c}\text { 신뢰성 높은 결과값을 도 } \\
\text { 출하기 위해서 인공지능 } \\
\text { 기반 요소 확보 필요 }\end{array}$ \\
\cline { 2 - 3 } 성 & $\begin{array}{c}\text { 인공지능 } \\
\text { 알고리즘 } \\
\text { 안정성 확보 }\end{array}$ & $\begin{array}{c}\text { 학습과 인지, 판단 프로세 } \\
\text { 스에 근거간 인공지는, 성밀 명 가 요 }\end{array}$ \\
\hline
\end{tabular}

(추진전략 4) 이해관계자관점의 민·군·정부·학 계 협력 강화

\begin{tabular}{|c|c|c|}
\hline $\begin{array}{l}\text { 필 } \\
\text { 요 } \\
\text { 성 }\end{array}$ & $\begin{array}{c}\text { 상생을 위한 } \\
\text { 협력 }\end{array}$ & $\begin{array}{l}\text { 민간기업, 정부, 학계 간 } \\
\text { 상생을 위한 윈-윈 형 협 } \\
\text { 력 필요 }\end{array}$ \\
\hline \multirow{3}{*}{$\begin{array}{l}\text { 상 } \\
\text { 세 } \\
\text { 전 } \\
\text { 략 }\end{array}$} & $\begin{array}{c}\text { 민간기업 간 } \\
\text { 협력 }\end{array}$ & $\begin{array}{l}\text { 인공지능을 이용한, 군용 } \\
\text { 특화 솔루션 개발 협력 }\end{array}$ \\
\hline & $\begin{array}{c}\text { 정부부처 간 } \\
\text { 협력 }\end{array}$ & $\begin{array}{l}\text { 국가 전략적 측면의 인공 } \\
\text { 지능 확대를 위한 } \\
\text { 정부 부처 간 긴밀한 협력 }\end{array}$ \\
\hline & 학계 간 협력 & $\begin{array}{l}\text { 국방 특화 인공지능 알고 } \\
\text { 리즘 연구 및 민간 기업으 } \\
\text { 로 우수한 인재 양성 }\end{array}$ \\
\hline
\end{tabular}


(추진전략 5) 법/제도 관점의 규제 샌드박스와 규제개혁 및 탄력적 지원

\begin{tabular}{|c|c|c|}
\hline $\begin{array}{l}\text { 요 } \\
\text { 성 }\end{array}$ & $\begin{array}{c}\text { 국방 } \\
\text { 인공지능 } \\
\text { 활성화 및 } \\
\text { 저변확대 }\end{array}$ & $\begin{array}{l}\text { 국방 인공지능의 활성화와 } \\
\text { 저변확대를 위해 정책적인 } \\
\text { 지원 필요 }\end{array}$ \\
\hline \multirow{3}{*}{$\begin{array}{l}\text { 상 } \\
\text { 세 } \\
\text { 전 } \\
\text { 략 }\end{array}$} & $\begin{array}{l}\text { 규제 } \\
\text { 샌드박스 } \\
\text { 활용 }\end{array}$ & $\begin{array}{l}\text { 국방 인공지능 신제품과 신 } \\
\text { 서비스의 개발 및 출시에 } \\
\text { 일시적 규제 면제 및 완화 }\end{array}$ \\
\hline & 규제 개혁 & $\begin{array}{l}\text { 인공지능 제품 및 서비스 } \\
\text { 개발에 걸림돌이 되는 규제 } \\
\text { 에 대한 과감한 개혁 }\end{array}$ \\
\hline & $\begin{array}{c}\text { 우수 } \\
\text { 중소기업 } \\
\text { 및 연구기관 } \\
\text { 비용 지원 }\end{array}$ & $\begin{array}{l}\text { 국방 인공지능의 건전한 선 } \\
\text { 순환 구조 형성을 위해 우 } \\
\text { 수 중소기업 및 관련 연구 } \\
\text { 기관의 비용 지원 }\end{array}$ \\
\hline
\end{tabular}

(추진전략 6) 국방 인공지능 거버넌스 확립

\begin{tabular}{|c|c|c|}
\hline \multirow{2}{*}{$\begin{array}{l}\text { 필 } \\
\text { 요 } \\
\text { 성 }\end{array}$} & 국방 특수성 & $\begin{array}{l}\text { 인명과 직접적인 연계성으 } \\
\text { 로 타 분야와 다른 특수한 } \\
\text { 관리가 필요 }\end{array}$ \\
\hline & $\begin{array}{l}\text { 이용의 } \\
\text { 건전성 }\end{array}$ & $\begin{array}{l}\text { 자국 안보 등의 공공 이익 } \\
\text { 증진에 활용하기 위한 통제 } \\
\text { 필요 }\end{array}$ \\
\hline 상 & $\begin{array}{c}\text { 가이드라인 } \\
\text { 연구 } \\
\text { 및 제시 }\end{array}$ & $\begin{array}{l}\text { 효과적인 관리와 통제를 위 } \\
\text { 한 군 범용적인 가이드라인 } \\
\text { 연구 및 제시 }\end{array}$ \\
\hline $\begin{array}{l}\text { 세 } \\
\text { 전 } \\
\text { 략 }\end{array}$ & $\begin{array}{l}\text { 인공지능 } \\
\text { 윤리가 } \\
\text { 반영된 } \\
\text { 성숙도 모델 } \\
\text { 연구 및 제시 }\end{array}$ & $\begin{array}{l}\text { 인공지능 윤리와 연관한 성 } \\
\text { 숙도 모델의 연구와 제시로 } \\
\text { 정량적인 관리와 지속적 개 } \\
\text { 선 수행 }\end{array}$ \\
\hline
\end{tabular}

6 가지 추진전략 중 가장 핵심적인 내용은 (추 진전략 1) 국방 인공지능 추진 로드맵 확립이다. 로드맵은 단기적으로 이루어질 수 있는 전략이 아니며 인공지능을 활용한 미래발전적인 측면에 서 매우 중요한 요소라고 할 수 있다. 최종 3단 계인Ecosystem을 구축하기 위해서 AI를 비즈니 스 측면으로 볼 때 서비스 제공기업(생산자 또는 공급자), 서비스 사용자(소비자) 및 데이터 저장 및 교류 플랫폼(분해자)로 구성 되어 있는 인공 지능 생태계 와 정부 등 인공지능 생태계에 영향 을 이해관계자 역할이 있다.[12]

\section{3 국방 인공지능 추진전략에 대한 제약사 항 분석과 극복 방안}

하지만, 국방 인공지능 추진에 있어 "국방" 이 라는 분야 특수성으로 인하여 추진전략에 제약사 항이 발생될 것으로 예상되며 주요 대상 항목은 그림 4 와 같이 추진전략 내 인력관점, 기술관점, 이해관계자관점, 법/제도관점의 4 가지 분야이다. 그 이유는 국방 인공지능 거버넌스와 Road Map 확립의 경우 인공지능의 전략적 활용 차원에서 작전의 운용과 임무, 주변국의 군사력 등으로 인 공지능 활용 전략이 수립되며 이를 토대로 Road Map 확립이 이루어지고 군 인공지능 운용 관리 및 통제, 프로세스화를 위한 국방 인공지능 거버 넌스 수립이 가능하다. 하지만 인력, 기술, 이해 관계자, 법/제도 관점에서의 추진전략에 대한 제 약사항은 실무적인 범위에서 운용환경과 운용자 원에 의해 다양하게 발생할 수 있다. 각 추진전 략 별 예상되는 제약사항은 아래와 같다.

\section{[인력관점의 제약사항]}

\section{○ 제약사항 1: 해외 인력 활용 제한}

- 군 보안과 연계 해외인력 활용의 제약성 발생

○ 제약사항 2: 외부 인력의 소극적 참여

- 국방분야라는 부담으로 인해 외부 인력의 소 극적 참여 


\section{[기술관점의 제약사항]}

0 제약사항 1 : 데이터 기밀성

- 군사보안에 의한 인공지능 학습용 데이터 접 근의 제한

○ 제약사항 2: 신기술에 대한 신뢰성

- 보수적이고 안정적인 기술 선호에 따른 신 기술의 낮은 신뢰도

○ 제약사항 3: 품질측정의 어려움

- 인공지능 학습의 추론 및 결과가 확률로 표현되어 품질 측정의 어려움

[이해관계자 관점의 제약사항]

$\bigcirc$ 제약사항 1 : 형식적 연대

- 각 구성원의 이익만을 고려한 형식적 연대 발생 가능

○ 제약사항 2: 정부부처 간 사일로 현상

- 군과 정부부처 간 조직 이기주의에 따라 비협조적 연대 발생 가능

[법/제도 관점의 제약사항]

○ 제약사항 1: 규제 샌드박스 대상 모호성

- 규제 샌드박스에 대한 대상 판단 및 판단 의 적절성 여부의 모호성

이제약사항 2: 규제 개혁에 대한 시간 소요

- 실 규제개혁까지 많은 시간 소요 발생

O 제약사항 3: 비용지원의 복잡성

- 비용지원을 위한 복잡하고 난해한 처리 및 프로세스 발생

\begin{tabular}{|c|c|c|c|c|}
\hline \multicolumn{4}{|c|}{$\begin{array}{l}\text { 국방 잉공지는 거버년스 } \\
\text { [주진전략 } 6]\end{array}$} & $\begin{array}{l}\text { 제양ㅅㅅ항 } \\
\text { 미 발생 영역 }\end{array}$ \\
\hline $\begin{array}{l}\text { [인련전럭적 2] } \\
\text { 2) }\end{array}$ & $\begin{array}{l}\text { 기숫ㄱㅆ정 } \\
\text { (주닌넉 3) }\end{array}$ & 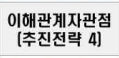 & 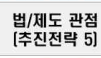 & $\begin{array}{l}\text { 제얏사항 } \\
\text { 찰생 영역 }\end{array}$ \\
\hline \multicolumn{4}{|c|}{$\begin{array}{l}\text { Road Map 확릴 } \\
\text { [추진전락 1] }\end{array}$} & $\begin{array}{l}\text { 제양ㅅㅅㅏㅏㅏㅇ } \\
\text { 미 날앵 영역 }\end{array}$ \\
\hline
\end{tabular}

그림 5. 추진전략 제약사항 발생 예상 영역 식별

Fig 5. Identify areas where constraints are expected to occur each strategy
이러한 제악사항은 추진전략 실행에 방해요소 로 작용되며 이는 반드시 극복되어야 한다. 하지 만 제약사항은 단시간에 극복되기 어렵기 때문에 Road map과 더불어 단계별로 해결되어야 한다. 각 제약사항에 대한 극복방안으로는 아래와 같 다.

\section{[인력관점의 제약사항 별 극복방안]}

$\bigcirc$ 제약사항 1: 해외 인력 활용 제한

- 극복방안

$\triangleright$ 국내 기술 성숙도를 높이기 위한 지속적 투자 시행

○ 제약사항 2: 외부 인력의 소극적 참여

- 극복방안

$\triangleright$ 적극적인 참여를 유도하는 혜택 부여

$\triangleright$ 세제 혜택 및 개발업무에 대한 병역 대체 인정

\section{[기술관점의 제약사항 별 극복방안]}

○ 제약사항 1: 데이터 기밀성

- 극복방안

$\triangleright$ 인공지능 개발에 접근성이 보장되는 데 이터 Set 개발

○ 제약사항 2: 신기술에 대한 신뢰성

- 극복방안

$\triangleright$ 실 운용 기반의 다양한 운용 시나리오 개발

$\triangle$ 제 3 의 전문 Test 팀 구축

○ 제약사항 3: 품질측정의 어려움

- 극복방안

$\triangleright$ 설명 가능한 인공지능에 대한 연구 투자

$\triangleright$ 국방 인공지능용 설명 가능한 인공지능 에 대한 투자로 품질측정의 명확성 제공

\section{[이해관계자 관점의 제약사항과 극복방안]}

○ 제약사항 1: 형식적 연대

- 극복방안

$\triangleright$ 참여 민간기업 및 학계에 제안참여 우선 권 및 용역과제 우선권 부여 
○ 제약사항 2: 정부부처 간 사일로 현상

- 극복방안

$\triangle$ 군 및 정부부처 모두 참여하는 $\mathrm{TF}$ 팀 구 축 및 팀원에 명확한 $R \& R$ 부여

[법/제도 관점의 제약사항과 극복방안]

○ 제약사항 1: 규제 샌드박스 대상 모호성

- 극복방안

$D$ 민·군·정부부처·학계의 규제 샌드박스 대 상 선정을 위한 컨소시엄 구성

제약사항 2: 규제 개혁에 대한 시간 소요

- 극복방안

$\triangleright$ 국방 인공지능 관련 규제개혁을 위한 패 스트트랙 설정

○ 제약사항 3: 비용지원의 복잡성

- 극복방안

$\triangleright$ 비용지원을 위한 각종 절차 및 프로세스 단축화

\section{4 제안한 추진전략에 대한 적절성}

제안한 추진전략에 대해서 적절성을 확인하기 위해 강대국과의 차별화 내용을 통해 적절성을 확인하고자 한다.

(추진전략 1) 국방 인공지능 추진 로드맵 확립 $D$ 기존 전략의 문제점

각 단계의 로드맵 미 달성에 따른 전체 로드 맵에 영향 발생

$D$ 차별화 내용

- 로드맵의 각 단계의 목표달성의 실패를 고 려 1,2 단계의 Iteration 방식의 로드맵을 제안

- 방위산업분야에 특화된 국방 인공지능용 Ecosystem을 제안

(추진전략 2) 인력 관점의 우수 인공지능 인 력 확보

$\triangleright$ 기존 전략의 문제점

인력양성에 많은 비용과 시간 소요 $\triangleright$ 차별화 내용

- 외부인력에 대한 인력 $\mathrm{Pool}$ 을 구성, 적시의 인력 활용 제안

- 적극적인 유도를 위해 한국 국방에 특화된 병역대체 혜택을 제안

(추진전략 3 ) 기술관점의 인공지능 기반 확 립 및 인공지능 알고리즘 연구

$\triangleright$ 기존 전략의 문제점

민감한 데이터에 대한 대응 부재, 인공지능

검증 관련 전략 부재

$D$ 차별화 내용

- 보안에 민감한 군 데이터를 극복하기 위한 접근성이 보장되는 데이터 Set 수립 제안

- 국방에 사용되는 기술의 고신뢰성 성격에 따라 인공지능의 신뢰성을 향상하기 위한 테스트 시나리오 개발과 전문 테스터 활용 제안

(추진전략 4) 이해관계자관점의 민·군·정부· 학계 협력 강화

$\triangleright$ 기존 전략의 문제점

구성원들의 이해타산적 접근이 발생될 경우 원할한 협의체 구성이 어려움

$\triangleright$ 차별화 내용

- 한국의 국방과 기술 간 공무처리 관점에서 기술 정책을 담당하는 과학기술정보통신부 와 국방방위 업무를 담당하는 국방부라는 관대관의 협력을 제안

(추진전략 5) 법/제도 관점의 규제 샌드박스 와 규제개혁 및 탄력적 지원

$\triangleright$ 기존 전략의 문제점

각종 규제 존재 시 관련 지원의 제약 발생

$\triangleright$ 차별화 내용

- 한국국방의 특수성에 대한 규제개혁을 위 한 패스트트랙 활용을 제안

- 한국국방의 규제개혁의 수단으로써 규제 샌드박스 활용을 제안 
(추진전략 6) 국방 인공지능 거버넌스 확립 $\triangleright$ 기존 전략의 문제점

여러 이해관계로 인해 형식적인이고 추상적 인 가이드라인으로 전락 가능

$\triangleright$ 차별화 내용

- 법제적인 부분과 가이드라인 뿐만 아니라 인공지능 윤리가 반영한 기술성숙도 모델 을 활용한 정량적관리와 지속적 개선이라 는 현실적 접근방식으로 제안

\section{4. 결 론}

민간 분야의 인공지능은 빠르게 확산되고 있 고 그 흐름에 맞춰 인공지능을 활용한 다양한 서 비스 상품이 출시가 되고 있다. 반면 국방 분야 는 인력과 기술 등의 여러 제약사항으로 인해 민 간 분야 대비 인공지능 적용 속도가 느리다. 하 지만 주요 강국에서는 인공지능이 대세인 현 기 술적 흐름과 군 전력의 우위를 위해서 능동적으 로 인공지능을 적용 및 활용하고자 하고 있다. 이에 따라 우리 군도 국방 인공지능의 활성화를 고민해야 하며 그 고민을 해결하기 위해서 여러 고려사항이 반영된 국방 인공지능 추진전략이 무 엇보다 필요하다. 본 논문에는 (1) 국방 인공지 능 추진 로드맵 확립, (2) 인력 관점의 우수 인공 지능 인력 확보, (3) 기술 관점의 인공지능 기반 확립 및 인공지능 알고리즘 연구 (4) 이해관계자 관점의 민·군·정·학 협력 강화, (5) 법/제도 관점 의 규제개혁과 탄력적 지원 (6) 국방 인공지능 거버넌스 확립이라는 총 6 가지의 추진전략과 각 전략의 필요성 및 상세 추진전략을 제시하였다. 아울러 추진전략을 실행함에 따라 관련된 제약사 항을 예측, 분석하고 분석 된 제약사항에 대해 극복방안을 제안하였다. 하지만 현 한국의 국방 인공지능은 강대국과 비교하여 다소 늦은 감이
있다. 하지만 본 논문에 제시한 추진전략을 활용 함으로써 국방분야의 인공지능 저변확대를 위해 초석을 다질 수 있을 것으로 기대한다. 본 논문 에 제시한 추진전략과 한국이 구축한 우수 ICT 인프라, 오랜 기간 축척한 첨단 기술 개발의 노 하우, 해외 의존성이 높았던 국방기술의 국산화 저력 및 자주 국방의 열정에 대한 추진력을 한 곳으로 집중한다면 강대국의 국방 인공지능 수준 으로 빠른 시간 내 충분히 도달할 수 있을 것이 라 판단한다.

\section{참 고 문 헌}

[1] 관계부처 합동, "인공지능 국가전략", 2019.12, https://www.korea.kr/common/ download.do?fileId=190114031\&tblKey=GMN

[2] 김돈정, “음성인식 가상비서 기술 동향 및 전망”, KEIT PD 이슈리포트 2019-4월호 : 이슈 1 (음성인식 가상비서 기술 동향 및 전 망), https://itech.keit.re.kr/index.do\#detail| 03040100|/comm/retrieveBlltDetail.dol.sub_c on $\mid$ searchCdtn $=\&$ searchKeyword $=\&$ pageInde $\mathrm{x}=14 \& b \mathrm{bd} d \mathrm{~d}=\mathrm{S} 0000010 \& b \mathrm{llt} \mathrm{Seq}=44294 \&$

[3] 과학기술정보통신부, "I-Korea 4.0 실현을 위한 인공지능(AI) R\&D 전략”, 2018. 05, https://www.k-ai.or.kr/kr/participate/refere nce.php?bbs_data=aWR4PTQ4MCZzdGFydF BhZ2U9MTAmbGlzdE5vPTEzJnRhYmxlP WNzX2Jic19kYXRhJmNvZGU9dGFiNV9jMi ZzZWFyY2hfaXRlbT0mc2VhcmNoX29yZG $\mathrm{VyPQ}==\% 7 \mathrm{C} \% 7 \mathrm{C} \& b g u=$ view

[4] 심진보, "글로벌 주요국들의 지능화 중점 추 진 분야”, ETRI Insight Report 2019-55 : 국가지능화 특집, $\mathrm{https}: / / \mathrm{ksp}$.etri.re.kr/ksp/ plan-report/read.htm?id=764

[5] 우상근, "인공지능(AI)을 선도하는 주요국의 핵심전략”, IT \& Future Strategy 보고서 제12호, 2018. 12. 15, https://toughw.tistory. com/attachment/cfile30.uf@9945E8445C75CC C6217CBA.pdf 
[6] 김동철, “글로벌 $\mathrm{AI}$ 주도권 강화를 위한 미 국의 AI 정책동향”, ICT SPOT ISSUE SPOT 2019-25, 2019. 12. 17, https://www. itfind.or.kr/admin/getFile2.htm?identifier=02 -001-191218-000001

[7] THE WHITE HOUSE OFFICE OF SCIENCE AND TECHNOLOGY POLICY, "Summary of the 2018 white house summit on AI for american industry", 2018. 05. 10, https://www.nitrd.gov/nitrd groups/images/2/23/Summary-Report-ofWhite-House-AI-Summit.pdf

[8] 최근하, 오재진, 김영길, “美 국방부 및 육군 의 인공지능 $(\mathrm{AI})$ 전략이 한국군에 주는 시 사점”, 한국방위산업학회지 제 27 권 제1호, 2020년, pp.41-52, ISSN: 1738-6144

[9] 한국경제연구원 보도자료, “韓, $\mathrm{AI}$ 인재 경 쟁력 韓·中·日 3국 중 꼴찌, 인력 부족률 60.6\% 달해", 2019. 12. 16 http://www. keri.org/web/www/news_02?p_p_id=EXT_B BS\&p_p_lifecycle $=0 \& p \_p \_s t a t e=$ normal $\&$ p_p _mode=view\&_EXT_BBS_struts_action= $\% 2$ Fext\%2Fbbs\%2Fview_message\&_EXT_BB S_messageld $=355865$

[10] 조재규, "국방 인공지능 인프라 분석 및 발 전방안”, 국방정책연구 2020년 겨울(36-4) 통권 130호 pp.109-146, DOI : 10.22883/ jdps.2021.36.4.004

[11] 김길수, "인공지능 거버넌스에 관한 탐색적 연구”, 한국자치행정학보 제33권 제2호(2019 여름), pp.219-236, DOI : 10.18398/kjlgas. 2019.33.2.219

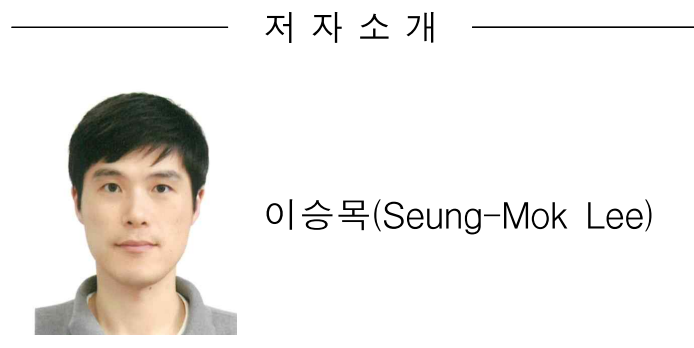

2009 경북대학교 전기전자컴퓨터학부 졸업 2009 현재 : 한화시스템 근무

<주관심분야> 항공전자, 인공지능, 임베디 드, 소프트웨어 품질

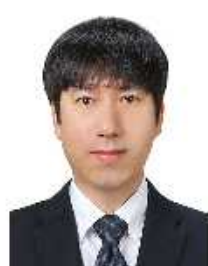

김영곤(Young-Gon Kim)

2009 포항공대 정보통신학 석사 졸업 2016 현재 : 한화시스템 근무

<주관심분야> DO-178/DO-330 인증, 디스 플레이, 컴퓨터 그래픽스

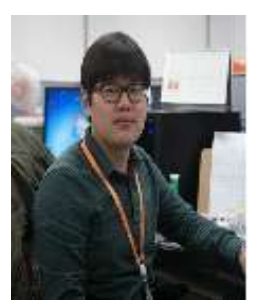

안경수(Kyung-Soo An)

2009 경북대학교 정보통신공학 석사 졸업 2002 현재 : 한화시스템 근무

현재 : 한화시스템 항공시스템팀장

<주관심분야> 임무컴퓨터, 대화면 시현기 